\title{
Effect of Olive Leaves Extract on Lipid Profile, Glucose and Feed Intake of Japanese Quail
}

\author{
Tawheed Ali Azeemi ${ }^{1,}$ Mohammad Asif ${ }^{2}$, Merhatam Niazi ${ }^{3}$

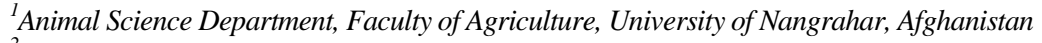 \\ ${ }^{2}$ Department of Histopathology, Faculty of Medcine University of Nangrahar, Afghanistan \\ ${ }^{3}$ Animal Science Department, Agriculture, Faculty, Nangrahar University
}

\section{A R T I C L E I N F O}

Article history:

Received 23 May 2015

Accepted 20 October 2015

Available online, ISSN: 2148-127X

Keywords:

Japanese quail

Olive leaf extract

Cholesterol

Triglycerides

"Corresponding Author:

E-mail: tawheedn@gmail.com

\begin{abstract}
A B S T R A C T
In Afghanistan most times people are drinking olive leave tea for prevention and decline of higher lipid and glucose level, therefore the objective of the current study was to find out whether olive leaf extract is having any effect on blood metabolites. The Japanese quail has been used for biological studies because of its easy management and large numbers in limited area. In this experiment quails (100 male and 100 female) were reared on a farm owned by the Department of Animal Science of Agriculture Faculty of Nangrahar University. Quails were kept under optimum environmental conditions during rearing period $\left(20-22^{\circ} \mathrm{C}\right.$ and $65 \%$ relative humidity). The adaptation period was 10 days. Feed was given adlibitum during $24 \mathrm{~h}$. In this study we had five treatments T0 served as control without olive leafextract, T1 $(1 \mathrm{~g} / \mathrm{L}), \mathrm{T} 2(2 \mathrm{~g} / \mathrm{L}), \mathrm{T} 3(3 \mathrm{~g} / \mathrm{L})$ and $\mathrm{T} 4(4 \mathrm{~g}$ of olive leaf $/$ litter of drinking water). Each treatments continued for 4 weeks at the end of week. By increasing level of the olive Leaf extract blood glucose, cholesterol and triglycerides levels declined significantly from 509 to $422.5,204$ to 44.5 and 245 to $192.5 \mathrm{mg} / \mathrm{dl}$ respectively.
\end{abstract}

\section{Introduction}

Olive leafs have been used as medication in different times for its health benefits and flavor. The health benefits included are anti- aging, immunostimulator, antibacterial (Bisignano et al., 2001), antifungal, anti-viral (Fredrickson, 2000) and anti-inflammatory (BenaventaGarcia et al., 2000).

Olives leaves contain ingredient which possess hypocholesterimic and hypoglycemic activities, these substances arelingstoride, hydroxytrosol, verbascoside, luteolin, olivine, arigenine, oleanic, maslinic acids and olivine-diglucoside (Dekanski et al., 2007; Botsoglou et al., 2010) stated that microbial growth was inhibited by supplementation of olive leaves in poultry diet.

The Japanese quail has been used for biological studies because of its easy management and large numbers in limited area. According to Deka and Borah, 2008 studies quail possess an excellent resistance to diseases and economical viability compare to chicken.

Kreshi et al. (1997), reported that biochemical analysis of blood is not only a valuable tool for the health animal but is also a best way for clinical monitoring and diagnosis of diseases. Evaluation of blood biochemical shows the degree of in vital organs. Therefore the objectives of the present study were to investigate the effect and relation of olive leaves extract on feed intake, lipid profile and Blood glucose levels.

\section{Methods and Materials}

The quails (100 male and 100 female) were reared on a farm owned by the Department of Animal Sciences of Agriculture Faculty of Nangrahar University. Quails were kept under optimum environmental during rearing period (20- $22^{\circ} \mathrm{C}$ and $65 \%$ relative humidity).

The adaptation period was -10 days. Feed was given adlibitum during $24 \mathrm{~h}$. The calculated nutrient content of diet is below.

$\begin{array}{lrr}\text { ME } & : & 2925 \mathrm{kcal} / \mathrm{kg} \\ \text { Crude Protein } & : & 21(\%) \\ \text { Crude Fat } & : & 28(\%) \\ \text { Calcium } & : & 0.95(\%) \\ \text { Available Phosphorus } & : & 0.50(\%) \\ \mathrm{Ca} / \mathrm{P} & : & 2.1\end{array}$


Olive leaves were taken from olive orchard in Jalalabad city of Nangrahar province. The olive leaves were dried in shed for 4 days and then milled by grinder. Measured amount of mailed leafs were put in boiled water and left for 12 hours. After this period the extraction was added to drinking water In this study we had five treatments $\mathrm{T} 0$ served as control without any water supplementation, T1 (1g/L), T2 $(2 \mathrm{~g} / \mathrm{L}), \mathrm{T} 3(3 \mathrm{~g} / \mathrm{L})$ and $\mathrm{T} 4(4 \mathrm{~g}$ of olive leaf extract/ litter of drinking water). The Experiment continued for 4 weeks at the end of week.

Quails were slaughtered for blood samples. The blood samples for biochemical analysis were collected in sterile tubes without any anticoagulant and serum was separated within two hours of collection.

Total cholesterol concentration in blood serum was measured by Roeschau et al (1974) and the serum triglyceride was measured according to the Fossati and Prencipe (1982) method. The amount of feed was given daily and the refused amount was daily measured for feed intake.

\section{Statistical analysis}

The experimental data was analyzed by SPSS 16.0.1 statistical package programme (SPSS In., Chigao, IL, USA.) The general liner model function was used for the analysis of variance (ANOVA).

\section{Results and Discussion}

\section{Glucose}

The blood glucose level was significantly decreased from $509 \mathrm{mg} / \mathrm{dL}$ to $422.5 \mathrm{mg} / \mathrm{dL}$ with the increasing level of olive leaf extract. There was a significant difference between treatments $(\mathrm{P}<0.000)$ (Table 1). The mean of serum glucose levels was $470 \pm 10.85 \mathrm{mg} / \mathrm{dL}$. No differences between sexes have been found (Table 2). Our findings are in the same line with the study of R.Prakash Krupakaran (2013). The large amount of glucose in serum is due to the glucagon secreted by alpha cells of Islets of Langerhan and according to the El-Ghalid (2009) reports higher blood glucose level is due to higher gluconeogenic hormones.

\section{Cholesterol}

Serum cholesterol level $(173 \pm 7.75)$ was significantly decreased $(\mathrm{P}<0.000)$ from 206 to $144.5 \mathrm{mg} / \mathrm{dL}$ with the increasing levels of supplementation (Table 1). Extract supplementation did not have any effect on sex (Table 2). Lowering of serum cholesterol might be a cardioprotective effect of olive leaf extract.

\section{Triglycerides}

Serum triglycerides was significantly decreased from $245 \mathrm{mg} / \mathrm{dL}$ to $192 \mathrm{mg} / \mathrm{dL}$ with the increased level of olive leaf extraction (Table 2) $\mathrm{P}<0.000$. Supplementation levels did not have any effect on sex (Table 2) $\mathrm{P}<0.148$.

\section{Feed Intake}

Feed intake decreased significantly, as the olive leaf extract supplementation levels was increased (Table 2) The marked decline in above blood biochemical might be o reduced feed intake along alkaloids of olive leaf.

Table 1 Effect of Olive leaf extraction levels on blood biochemical.

\begin{tabular}{c|rcrc}
\hline Treatments & Glucose $\mathrm{mg} / \mathrm{dL}$ & Total Cholesterol mg/dL & Triglycerides mg/dL & Feed Intake g/day \\
\hline T0 & 509.5 & 206 & 245 & 33.5 \\
T1 & 495 & 191 & 232 & 30.5 \\
T2 & 482 & 173.5 & 212.5 & 29.5 \\
T3 & 445 & 147 & 202.5 & 26.5 \\
T4 & 422.5 & 144.5 & 192.5 & 25.5 \\
\hline P.Value & 0.000 & 0.000 & 0.000 & 0.000 \\
\hline
\end{tabular}

Table 2 Olive leaf extraction levels on blood biochemical of male and female quails.

\begin{tabular}{l|ccccc}
\hline Sex & Treatments & Glucose $\mathrm{mg} / \mathrm{dL}$ & Total Cholesterol mg/dL & Triglycerides mg/dL & Feed Intake g/day \\
\hline \multirow{5}{*}{ Female } & T0 & 510 & 220 & 255 & 33.5 \\
& T1 & 490 & 195 & 240 & 30.5 \\
& T2 & 481 & 178 & 220 & 29.5 \\
& T3 & 442 & 156 & 204 & 26.5 \\
Male & T4 & 420 & 148 & 230 & 25.5 \\
& T0 & 506 & 204 & 229 & 31.4 \\
& T1 & 485 & 200 & 210 & 30 \\
& T2 & 483 & 175 & 191 & 30.1 \\
& T3 & 438 & 140 & $216 \pm 6.47$ & 27.8 \\
\hline
\end{tabular}




\section{Conculsion}

Our finding are in agreement with previous studies done by R.Prakash Krupakaran (2013) showing that olive leaves extract decrease serum glucose, while it is the first time we have reported that olive leaves extract is decreasing other blood metabolites as well. Increased olive leaf extraction decreases the cholesterol level which is a good properties while higher level may decrease egg production due lowering of cholesterol. Olive leaf extraction supplementation should be in medium level for better health and production.

\section{References}

Benavente-Garcia O, Castillo J, Lorente J, Ortuno A, Del Rio JA 2000. Antioxidant activity of phenolics extracted from OleaeuropaeaL. leaves. Food Chemistry; 68: 457-462.

Bisignano G, Lagana MG, Trombetta D, Arena S, Nostro A, Uccella N, Mazzanti G, Saija A 2001. In vitro antibacterial activity of some aliphatic aldehydes from Oleaeuropaea L. FEMS Microbiology Letters; 198: 9-13

Botsoglou, E., Govaris, A., Christaki, E. \&Botsoglou, N 2010. Effect of dietary olive leaves and/or $\alpha$-tocopheryl acetate supplementation on microbial growth and lipid oxidation of turkey breast fillets during refrigerated storage. Food Chem.; 121: 17-22.
Deka K, Borah J. 2008.Haematological and biochemical changes in Japanese Quails Coturnixcoturnix Japonica and chickens due to Ascaridiagalli infection. International Journal of Poultry Sciences, 7(7): 704-710.

Dekanski D, Janicijevic-Hudomal S. 2007. Medicinal features of olive leaf (Oleaeuropaea L.). Praxis Medica; 35(1-2): 89-92.

El-Ghalid OAH, 2009. Exogenous Estradiol Blood profile, productive and reproductive performance of female Japanese Quails at different stages of production. Asian J. Poultry Science Journal 3(1): 1-8

Fossati P, Principle L. 1982.Serum triglycerides calorimetrically with an enzyme that produces hydrogen peroxide. Clin. Chem.; 28: 2077-80.

Fredrickson WR 2000. Method and composition for antiviral therapy with olive leaves. United States patent 20006117844. 2000 set $12.6,117,844$.

Karesh WB, Campo AD, Braselton E, Puche H, Cook RA. 1997. Health evaluation of free ranging and hand reared macaws (Ara spp.) in Peru. Journal of Zoo and Wild Life Medicine 28: 368277

Rraksh Krupakaran R. 2013. Serum Biochemical profile of Japanese quail, Indian Journal of Fundamental and Applied Life Sciences ISSN: 2231-6345, Vol.3 (1) January - March , pp. 183183/Kruparkaran.

Roeschau P, Bernt E, Gruber W .1974, Enzymatic determination of total cholesterol in serum's Kiln Chem. Kiln Biochemist.; 12: 226-27. 